\title{
$(\mathrm{cc})) \mathrm{BY}-\mathrm{ND}$
}

\section{The Princeton Dante Project}

\section{Robert Hollander, Princeton University}

History: The Princeton Dante Project (henceforth PDP) was the direct result of a suggestion by a former student of mine, Susan Saltrick (Princeton '78), that I should meet with Bob Stein, at that time (late 1994) one of the most impressive innovators in the field of so-called humanities computing, with the aim of developing a second large-scale Dante project. My initial response to Susan was that I was too busy with the first, the Dartmouth Dante Project (DDP), for which I had been serving as Project Director since 1982, even to think about a second. (The DDP was a communal effort, as would be the PDP, involving people on both sides of the technological divide, professors of literature in the Department of French and Italian at Dartmouth and computing personnel from that institution's Kiewit Computation Center.) Susan convinced me that no harm could possibly come from spending some time with Mr. Stein. And so the three of us did meet at his office in Manhattan, along with some of his associates. It is sufficient to report that, from the expert advice and encouragement I received from Saltrick, Stein, and Stein's collaborators, I was inspired to conceive a new project that would do many of the things for a student of Dante that the DDP was obviously not designed to do. That earlier project was tasked with doing a fairly simple chore: making machine-readable the most notable commentaries to the Commedia in the six hundred and sixty years separating the first commentaries from the current ones (1322-1982; we would eventually add three still more recent ones) and building a mechanism to search them effectively. Now that we had made significant progress with establishing that first Dante database, it was almost inevitable to envision an electronic edition of the poem with facing English translation (concerning which there will be more in the next paragraph). This "edition" would also have the following links: explanatory notes for nearly every passage in the poem; philological notes for verses containing problematic textual readings; and historical notes for things, places, and persons referred to in a particular verse. In addition, there would be links to all commentators in the DDP (then several dozen, now some seventy-five) who had dealt with the particular verse or passage under consideration. There would also be links to an Italian voicing of the poem, broken into tercets (the three-line unit that is the basis of the poem's structure): the user would have the option of hearing a single tercet, or the screen "page," or the entire canto. Finally, we 
would offer a small sampling of illustrations of various scenes in the poem, including the most celebrated series of these, that of the great nineteenth-century illustrator Gustave Doré, but also the much less well known but striking lithographs, one from all but one of the hundred cantos, by the twentieth-century artist Amos Nattini. (The Dali illustrations are also available by connecting to another site, as are a number of others.) In addition, there is a collection of maps and diagrams; these are not keyed to specific passages but serve as a sort of appendix. There were to be (and are) other features as well: Paget Toynbee's brief but full biography of Dante, along with a 1500-item bibliography of critical work referred to in the notes to the poem, as well as summaries of the contents of each canto.

The question of which translation to use was resolved by my wife, the poet Jean Hollander. I was on leave in Florence for the spring semester of 1997. We were living on the grounds of the former Machiavelli estate, across the Arno, with an enviable prospect of the center of the city, at eye level with the dome of the Duomo. One day in February, soon after our arrival, my wife found me looking over a piece of John Sinclair's translation, which I had chosen as the one we would use for the PDP and which we (I and graduate students Frank Ordiway and Lauren Scancarelli Seem) had modernized, getting rid of the worst cases of nineteenth-century poetic diction (e.g., "thee" and "thou," which both became "you"). When Jean examined a piece of that text she declared it to be unsayable. I reminded her that she had on occasion taught Dante to students using Sinclair's translation and challenged her, asking if she thought she could do better. Her answer was to pick up the several pages of the first canto of the poem and carry it to her work space in that former Machiavelli dovecote in which we were so happily ensconced. A few days later she handed me a similarly-sized document, her revised version of Sinclair's prose, now become free verse in Jean's reshaping. What she presented was, for all its problems, a clear improvement over the original. I asked Jean if she wanted to translate the entire poem with me. She said she did, even after I warned her of how much work she was taking on. We published the first volume of our translation with Doubleday in 2000, acknowledging our debt to Sinclair several times in an opening note. In the successive versions after the first that we did of each canto, Sinclair disappeared from our view as we worked from Dante's words rather than his translation. On the other hand, we still insist on our original debt to Sinclair, even as we did in that prefatory note eleven years ago.

In the winter of 1996 I made application to the NYU "computer boot camp" directed by Red Burns, a faculty member at NYU, in association with Bob Stein. I was accepted and spent most of the month of June commuting by rail from 
Princeton to Greenwich Village, where I had in fact grown up. The project went extremely well. The first day I drew on the blackboard a model of the design of the project as I foresaw it. I wish that I had made and kept a copy of that diagram, for that basic design was close to what we eventually produced -- a disk with representations of the various components of the PDP. I am grateful to everyone connected with that boot camp, teachers, trainees at NYU, and fellow students alike. That experience ensured that the PDP began its life on the best imaginable footing. When I went to talk to Princeton's humanities computing people, then led by Jacqueline Brown, the reasons for creating the PDP practically explained themselves. To my great pleasure, Princeton wanted to undertake the project. And now we needed to solve the least interesting but not inconsequential part of the problem: money.

The National Endowment for the Humanities (NEH) had funded, bless its heart, the DDP at a time in which few humanists (at least few serving on NEH panels) knew anything about computers (1983). NEH had earlier funded one part of David Packard's huge Greek project, "Ibycus," which eventually resulted in the computerized Thesaurus Linguae Grecae. The Endowment's official position was, perhaps understandably so at that time, that humanities and computers were a marriage that needed to be studied more carefully before federal dollars should be advanced in their further support. It is surprising (as I know because I was allowed to read, as were all applicants in those days, the anonymous versions of the panelists' responses and found that these were as untutored as one might have feared) that the project came through with funding. I think (this is merely my conjecture) that the then-director of the NEH's Division of Research, Harold Cannon, had seen the promise of the DDP and had shepherded the proposal through a very rocky pasture indeed. We later received further funding from NEH for a necessary second cycle during 1985-88. To my surprise (and no little delight) Dartmouth managed to put the whole thing together for an opening ceremony, with, as I recall, a dozen commentaries running on their mainframe, on October 8, 1988. . My most amusing memory of that celebrative weekend is the response of a visiting Dantean rival, a person who had already frequently not been impressed by my work, who peered into a computer screen and said, exasperatedly, "Oh, it's just Benvenuto da Imola," as though it were normal to look at a screen and see a fourteenth-century commentary to Dante, as though the whole project were a step backward from going to the university library and opening up a volume of the five-volume set of the Vernon/Lacaita edition of 1887. The DDP, in the nearly quarter century since it opened to consultation from around the world, has in excess of a million contacts per year from, in a given month, more than fifty countries, led, unsurprisingly, by Italy. 
That was then and the PDP was now. I thought the proposal I had drafted was the best one I had ever submitted for financial support. This time, however, the NEH response was not only negative, but firmly so. I thought that the PDP had been held hostage to its successful elder sister. Or perhaps my view of the younger sister overrated her charms. At any rate, Princeton's financial involvement "paid" for more than Dartmouth's and the total amount of cash required was, most fortunately, not nearly so much. The DDP eventually had cost over a million dollars in cash from a number of foundations and individuals. The PDP was much less exigent with regard to outside funding for four reasons: (1) digitization of materials had become less expensive in the intervening dozen years; (2) there were far fewer materials to be made machinereadable in the first place; (3) Princeton put more of its own resources into this effort than Dartmouth had, mainly a goodly piece of time from five or six of its employees in computing; and (4) most of the project was essentially completed within a single academic year. Major support for the PDP came from the Andrew W. Mellon Foundation (as is frequently the case, the first to see merit in a challenging proposal), the Gladys Krieble Delmas Foundation, and the Edward T. Cone Foundation. Within Princeton the project benefited from a grant from the 250th Anniversary Fund for Innovation in Undergraduate Education. In 2000 there were two substantial gifts from individuals: George Castell and Paul Gridley. (Mr. Gridley also helped to fund the renovation of the Dartmouth Dante Project in 2004.) The Clover Foundation provided an emergency grant to ensure the completion of the first stage of the project in the fall of 1998. Where the DDP had had to raise more than $\$ 1,000,000$ in cash, the PDP needed roughly one fifth of that amount, since the University supplied, as its contribution, so much of the necessary brainwork at no charge to the project.

There were nine of us charged with designing and building the PDP and we met fairly frequently during the course of that academic year. The cast of characters included four people who worked for CIT (Computing and Information Technology -- now OIT, Office of Information Technology): Kirk Alexander (School of Engineering), Peter Batke (CIT), James Beldock (independent software consultant), Paula Brett (CIT), James Chu (CIT), Robert Hollander (French and Italian), Catherine Kunicki (independent designer), Lauren Seem (graduate student in Comparative Literature), and Jonathan Wilding (CIT). There were several others, as well, including Kirk Alexander's younger colleague, Kevin Perry. He and Paula Brett are the main contacts for the few items of housekeeping that are required now, a dozen years later, on an ongoing basis. Indeed, I spent a good part of the early summer of 2011 reviewing and updating with the two of them the entire database, some of which had fallen into disrepair or obsolescence. 
Function: Since the PDP offers a tutorial that users may consult and since much of what the database offers is straightforwardly intuitive, those who have never or rarely visited the site are here invited to have a look at the online tutorial or, if they prefer, at the project itself. The tutorial runs fewer than thirteen minutes and will give a concrete sense of what is contained in the database and how one consults those data: http://etcweb.princeton.edu/dante/tutorial/index.html.

Some observations about the project's functionality follow. In 2004 I experienced an illness that left me housebound for several months. I would not have been able to "do Dante" in the way that I have learned to trust and enjoy without the PDP -- handsome remuneration for my share in the toil necessary to create it. Most of the work that I have published on Dante is based in the close study of a particular text or series of texts. (Given that predilection, it will not seem accidental that I have written a commentary on the Commedia -- it also is contained in the PDP.) Thus the PDP reflects its designer's way of conceptualizing his own way of approaching this great poem. It is important to know that Dante considered himself not only the maker of his poem, but also its first commentator. In addition to its wider concerns, The Epistle to Cangrande (1318?) is in part dedicated to analysis of the first sixteen verses of the Paradiso. It is true that, in the years between 1819 and the present, more than a few, those who do not think the lines of argument found in the epistle are "Dantean" in nature, have raised their voices in dissent. The reader should know that the present writer is of the strong opinion that the document was, in fact, composed by Dante (see my polemically titled Dante's Epistle to Cangrande, Michigan 1993) and is in accord with what the poem exhibits as its own instruction on how it should be interpreted -- a view that is increasingly shared among Dantists, if not by the few remaining hard-line dissidents. Whether or not Dante was the author of the first one, no other literary work in the Western tradition has been the focus of so many line-by-line commentaries. And that fact tells us something about its author and his method of writing. Dante, in fact, practiced self-exegesis (he was perhaps the first in Western letters to do so) in two of his preceding works, the Vita nuova and the Convivio. It is thus not at all surprising to find him doing so, if fragmentarily, in response to his own Commedia.

The focus of the PDP is on the meaning of the smaller units of the poem -- a single word, a single verse, a single tercet. This is not to suggest that larger issues or themes -- empire vs. republic, the role of the papacy in the political world, the efficacy of prayer, the freedom of the will, etc., etc. -- do not come frequently into play, both in the poem and in the notes that accompany it, but that larger concerns must always be approached with the 
details contrived by the poet much in mind. The three kinds of notes available in the text of every canto (interpretive, historical, and philological) reflect different concerns but are all appropriate to nuanced study. (Currently only the first six cantos have philological notes, but the rest are coming in the next two years, as part of my next project, a three-volume study of 101 cruces in the poem, one from each canto.) The entire project also benefits from the presence of all of Dante's less known and revered works, not only the Vita nuova, De vulgari eloquentia, Convivio, and Monarchia, but his nearly one hundred vernacular lyrics, his four Latin eclogues, his thirteen epistles, and a treatise (the Latin Questio de aqua et terra). All of these are accompanied by standard English translations. And all of them are searchable by the search mechanism that was designed into the project early on, mainly, if memory serves, by Peter Batke.

The historical notes all derive from Paget Toynbee's Concise Dictionary of Proper Names and Notable Matters in the Works of Dante (Oxford: Clarendon Press, 1914), as revised by Charles S. Singleton (Oxford: Clarendon Press, 1968). These notes remain the single most helpful assemblage of such material in the PDP. The fact that, for many items, the user is able to choose between a shorter and a longer version of the material turned up in a search is a boon. Let us examine the situation confronting someone who wants to know more about the mysterious prophecy of the "five hundred ten and five" (cinquecento dieci e cinque; Purg. XXXIII.43). This example also serves to illustrate a potential problem facing users of this mechanism in the database. If one types in these four Italian words in the "Toynbee Title Search" box, one gets a null result. However, typing in the same four words in the "Toynbee Text Search" box takes the user to the internally coded entry "DXV" (the Roman numerals for the number 515 by which scholars refer to this particular bit of business. The PDP does not do all the users' thinking for them and there are and always will be some rough edges). Generally, once one has a "hit," the default value for display is the condensed version, the "summarized entry," brief and to the point; it may give searchers who want to get an overall sense of the problematic nature of an item encountered in the text of the poem all that they need. An option exists at the bottom of the "summarized entry" to access the "long entry"; doing so, one finds that it includes far more information, including, on occasion, some bibliography, should the user want to have such. In my opinion, the Toynbee material is some of the most valuable available in the PDP, and I remain thankful to Oxford University Press for granting us permission to include this material in the database.

If this Toynbee option is perhaps the quickest and most helpful way of bracketing the elements of a certain kind of query, it hardly exhausts what is available within the PDP. If one wants to know what the person who designed 
the project thinks about a particular passage, one clicks on the "Commentary" portion of the menu for the verse and gets a good deal more information. However, one obvious problem that remains is that the user now has the views of only two individuals. What if he or she really wants to deal with centuries' worth of disagreement over this, one of the most contention-causing loci in the poem? Here's where the PDP can be most helpful, taking the user to all responses found over the past six hundred and ninety years in a commentary tradition that is simply the richest ever to have grown alongside the text of a single poem. The fifty-four of the seventy-five glossators (some of whom did not finish their commentaries while others may have ducked this difficult passage) collected in the Dartmouth Dante Project (of the perhaps two hundred commentaries that exist, some completed, others abandoned, in the annals of Dante scholarship) do not, among themselves, guarantee that the Dantist who consults them will come away no more confused than when entering the selva oscura of this difficult poem. What they do unfailingly reveal is the difficulty and attractiveness of this poem. It has had a hold on readers for nearly eight centuries now -- and there is no sign that its attractiveness is waning. On the contrary, the extraordinary success of the actor Roberto Benigni, not only in Italy, but in the rest of Europe and in North and South America, who has been bringing Dante to a wider audience in his road show "Tutto Dante," tells us that, in a time not noted for its appreciation of great literature, Dante's success is wider than ever. To say that the Commedia is the greatest single poem ever written does not represent an obviously untrue claim; in any case, there are probably less than a handful of other plausible contestants for such a claim. Suffice it to say that the Commedia has enriched many a life and that the odds very strongly favor its continuing to do so.

It may be helpful to add that, if a user has questions or suggestions, there is a form for communicating with us on the PDP welcome screen (one simply clicks on the legend "Bugs? Comments?"). In the twelve years of our existence we have had quite a few of these, some pointing out typographical and other mechanical errors (assistance that is most welcome), others asking for information not available within the parameters of the database. While a few of these questions have not been answerable (at least not by me), I have responded immediately to every one of them and promise to do so in the future. 